Bond University

Research Repository

\title{
Promoting Scotland, diplomacy and influence through sport
}

Jarvie, Grant; Murray, Stuart; Macdonald, Stuart

Published in:

Scottish Affairs

DOI:

10.3366/scot.2017.0161

Licence:

Other

Link to output in Bond University research repository.

Recommended citation(APA):

Jarvie, G., Murray, S., \& Macdonald, S. (2017). Promoting Scotland, diplomacy and influence through sport. Scottish Affairs, 26(1), 1-22. https://doi.org/10.3366/scot.2017.0161

\footnotetext{
General rights

Copyright and moral rights for the publications made accessible in the public portal are retained by the authors and/or other copyright owners and it is a condition of accessing publications that users recognise and abide by the legal requirements associated with these rights.
}

For more information, or if you believe that this document breaches copyright, please contact the Bond University research repository coordinator. 
Scottish Affairs 26.1 (2017): 1-22

DOI: $10.3366 /$ scot.2017.0161

(C) Edinburgh University Press

www.euppublishing.com/scot

\title{
PROMOTING SCOTLAND, DIPLOMACY AND INFLUENCE THROUGH SPORT
}

\author{
Grant Jarvie, Stuart Murray and Stuart Macdonald
}

\begin{abstract}
Sport is being used by a number of countries to raise profile, and create influence. Sports diplomacy has an increasing presence in terms of theory, practice and evidence within international relations. Sports diplomacy may occur both within sport and through sport. The channels through which this is facilitated are complex. Scotland has much to learn from places such as Australia that have put in place a dedicated four-year sports diplomacy strategy. The article sets out to answer key questions and doing so suggests that Scottish sport is capable of making the art of the possible, possible, but that Scotland has yet to grasp the opportunities provided by sport's global currency. The article concludes by making six recommendations.
\end{abstract}

Keywords: Sport, diplomacy, influence, international relations, cultural relations

Grant Jarvie is Chair of Sport and Head of the Academy of Sport at the University of Edinburgh having held established chairs at two other UK universities. He has served as University Vice-Principal and Acting Principal, Chair of Scottish public bodies and is a visiting research professor with the University of Toronto (Grant.Jarvie@ed.ac.uk).

Stuart Murray is a Senior Lecturer in International Relations and Diplomacy at Bond University, Australia, author/editor of many publications in the Diplomatic Studies field, a fellow at The Academy of Sport, Edinburgh University, and Associate Editor of the Journal Diplomacy and Foreign Policy.

Stuart MacDonald is the founder and Executive Director of the Centre for Cultural Relations at the University of Edinburgh. Stuart is a former senior civil servant who had advised Ministers in both the UK and Scottish Governments on a wide range of policy issues. He is a former Head of Strategy for Tourism, Culture and Sport in the Scottish Government and led work on the establishment of the UK National Lottery and the implementation of the Scotland Act in Home and Social policy. 


\section{Grant Jarvie, Stuart Murray and Stuart Macdonald}

\section{Introduction}

This article proposes that Scotland should learn from other countries where sport has been used as an effective tool for international relations and development. ${ }^{1}$ The benefits case for using sport to promote Scotland outweighs any of the risks but a more thoughtful, networked and collaborative approach is needed, both nationally and internationally. International relations, diplomacy and foreign policy can at times seem remote from everyday experience. Sport on the other hand connects with people from all walks of life. The Scottish Government has access to effective UK channels of influence. It has an International Directorate, Framework and the Scottish Parliament has an active European and External Relations Committee (EERC), which offers a degree of scrutiny to Scotland's international framework, country plans and international development activities. In order to maximize influence, persuasion and the winning of friends, this paper argues that the Scottish Government should make more use of the many sporting avenues that can help it connect with cities, communities and nations across the world. Sport's global and local currency should be used to the full.

Sport is a complex, confusing and at times risky playing field. It is currently facing a crisis of governance in some quarters, and internationally it involves many actors, agencies, institutions, clubs and administrative entities all competing for space and political traction in a crowded landscape. The language of international cultural relations is also crowded with terms such as hard power, soft power, cultural diplomacy, cultural relations, cultural policy, foreign policy, and public diplomacy further confusing the interplay between sport, society and politics. We need a new language around sport and cultural relations, if not a new modus operandi, if Scottish sport is to maximize the opportunity presented by sport's global currency. ${ }^{2}$ We also need to know more about the conduct of diplomacy in the sports world, as well as the real value of sport as a low-cost, high profile tool for external relations.

Scotland is not a diplomatic actor in the sense that it is not a fully independent, sovereign nation state with diplomatic staff, representation and foreign embassies. It operates within the diplomatic framework of the UK. Despite the linking of culture and external relations in the portfolio of the Cabinet Secretary, the fact that sport is clearly a very important part of culture, an impressive sporting history and more recent scrutiny, profile, and success it is surprising that Scotland has not yet fully grasped the potential of sport in its international activities, promotion, relations and development. A number of countries are now recognising this. This article describes, evidences and critiques such endeavours before applying them to the Scottish case. 


\section{Diplomacy and Influence through Sport}

The proposition set out in this article is that sport is capable of making the art of the possible, possible, and that Scotland, as a 'sub-state' transnational actor should embrace the possibilities that are provided by sport's global currency. The potential rewards are many: greater influence, effective cultural relations in an increasingly tense world, increased connectivity, enhanced sport for development, stronger partnerships, added value from the sport spend, showcasing Scotland and taking the lead on issues of sports integrity and innovation.

This article does not seek to provide a terminal set of assumptions on sports diplomacy in the Scottish context. It brings together two different research programmes on (a) sport, and (b) diplomacy, conducive to enhancing interest, discussion, theory and policy on how Scotland might better use sport to maximise people-to-people links, international development, cultural, trade, investment, education and tourism opportunities. It aims to begin a discussion and interaction between relevant theorists and policy makers interested in the potential of a Scottish sports diplomacy strategy. In order to address such a proposition four questions are considered:

- Briefly, what is the nature of Scottish sport?

- What is the current debate surrounding sport and international relations?

- What is the state of theory and practice involving sports diplomacy?

- How can Scotland increase its influence through sport?

\section{The Scottish State of Play}

Scotland's wide and varied history, networks and influence illustrate the potential of Scotland's sporting assets. These can be capitalised upon a lot more to enhance Scotland's ability to interact internationally. Sporting relationships should not be constrained by sport and health alone but further enable government relations, cultural relations, business relations and much more.

Scotland has given a lot to the world of sport (http://www.sshf.co.uk.). Sport is woven into Scottish, history, culture and identity. Some of our streets are named after sports, it has featured in legislation, provided an avenue of social mobility for some and been the focus of Royal attention. That Scotland has given a lot to the world of sport and its local communities is not in question. At the time of writing Scots continue to hold positions of influence 


\section{Grant Jarvie, Stuart Murray and Stuart Macdonald}

within world of sport and yet, unlike in Denmark, just how many positions of influence a small country like Scotland should actually have in order to increase its international influence through sport is a question that is rarely, if at all, strategically discussed or championed in Scotland. In July 2015 Louise Martin was elected first ever-female President of the Commonwealth Games Federation while Ann Budge became one of the very few football chairs to have introduced a living wage to any football club in the UK. She thus added to a long list of actions that have involved Scottish sport contributing to social welfare. In August 2015 the Braemar Royal Highland Games and Gathering celebrated its two hundred year anniversary. Its origins are in the Braemar Wright Society of 1815 whose formation was as a mutual assistance society to support the sick, funeral expenses and allowances for widows. A $0.7 \%$ rule applied at football clubs such as Celtic means that $0.7 \%$ of annual turnover funds social causes through the clubs foundation. The point being that Scotland has a long tradition of using sport to enable health and social welfare but that Scotland is arguably held back by placing sport within a portfolio that constrains the proven capability of sport to deliver for other areas.

Even where sport is used to advance health and social welfare, challenges remain, but it is not necessary or desirable to list all of these in this article. Access to sport for those living in poverty remains an issue, a fact that was evidenced in a recent London School of Economics (LSE) UK report on poverty and access to sport for young people (LSE, 2015). Perhaps most crucially, leaving school is a cliff edge for sport and for general involvement in social activities and clubs. Post-school, social networks become looser and friends tend to prefer 'hanging out', drinking together, smoking and other less formal and structured activities. These activities are frequently reported by young people over 18 as their most common forms of leisure, but also by younger people too. Young parenting also acts as a limit on young people's involvement.

The governance of sport in Scotland is complex but manageable, given the size and scale of the country, in comparison, for example, to Canada or Australia. Following on from the 2014 Scottish Referendum campaign, a change of First Minister and subsequently the cabinet, the sport portfolio became the responsibility of a Minister for Sport, Health Improvement \& Mental Health, a junior Ministerial position, responsible to the Cabinet Secretary for Health, Well-being and Sport. The latter is a full cabinet position. (Within the UK Parliament sport is linked to Culture through the Department of Culture, Media and Sport) The same arrangements are in place following on from the 2016 Scottish election ministerial re-shuffle. Sport is largely a devolved responsibility of the Scottish Parliament, with the exception of UK 


\section{Diplomacy and Influence through Sport}

sport funding. It is worth noting that UK sport received $29 \%$ uplift in budget as a result of the UK Chancellor's 2015 autumn statement. By contrast the Scottish budget allocation for sport, according to SPICE figures, showed a $37 \%$ cut (SPICE, 2015).

In terms of public accountability, the Scottish Parliament takes an active interest in sport through its Health and Sport Committee and there is an active cross party sports group serviced by the Scottish Sports Association. The national sports agency - sportscotland - is a Non-Departmental Public Body, which, while independent, reports to the Minister for Sport, Health Improvement and Mental Health. The Chair has to be approved by the aforementioned Minister and the agency acts as the Government agency for sport. In addition, there is a range of other bodies with specific remits and responsibilities:

- The thirty-two Scottish local authorities remain the major suppliers of sport, physical activity and physical education in Scotland. They deliver sport and physical recreation through Sport and Leisure Trusts, which spend around f700m a year;

- The National Strategic Group for Sport and Physical Activity underpins the governance structure on strategic commitments under the Government's Physical Activity Implementation Plan;

- Active Scotland, an NHS body, acts as a mechanism to support the physical activity workforce;

- The Scottish Sports Association (SSA) brings Scottish Governing Bodies of sport together with a wide range of partners with the aim of ensuring that sports policies, and those that impact on sport, work in harmony;

- The Commonwealth Games Council for Scotland is the lead body for Commonwealth Sport in Scotland and its membership is made up of the Scottish governing bodies of the twenty six Commonwealth Games Sports;

- Education Scotland has responsibility for outcomes from school education related to physical education, activity and sport and has recently reduced its commitment to physical education.

A number of very recent events have placed a spotlight on Scottish sport. 2014 saw the Scottish Independence Referendum produce both yes and no camps and spokespeople for sport; the Glasgow Commonwealth Games and the hosting of the Ryder Cup. In the run up to the 2015 UK General Election 


\section{Grant Jarvie, Stuart Murray and Stuart Macdonald}

many of the political parties, including Scottish parties, produced manifesto discussions rather than pledges on Scottish sport. ${ }^{3}$

The evidence base to inform aspects of Scottish sport has improved and yet unlike Canada, Denmark, and Holland no dedicated research council funding for sport exists in the UK. In terms of numbers, contemporary Scottish sport (2014-2015) could include the following:

- 150 community sports hubs with 994 sports clubs and 114,577 active members.

- Sports governing body membership has risen by $8 \%$ to 16,000 , between 2012 and 2015.

- $£ 10$ million directed into 2014 Legacy Active places fund.

- 2,587 clubs linking with schools.

- Sport and leisure trusts in all 32 local authorities.

- $£ 41$ million invested in facilities between 2011-15 by sportscotland.

- 63 Commonwealth Medallists from 2014.

- The creation of a $£ 30$ million National Sports Performance Centre and a $£ 16$ million National Centre for Para-Sport - the first in Europe.

- The Commonwealth Games were delivered within a budget of f575.6 million.

- Heart of Midlothian football club is the first Scottish Premier Football League Club to introduce a living wage for all employees.

Research by Kelly (2015) shows that the sports which make the greatest contribution to health are swimming, recreational football for men and women and recreational jogging. The Scottish Health Survey (2014) shows a Scotland in which; the most popular sporting activities amongst all adults included in the survey were: working out at a gym (17\%), exercises (17\%), swimming (14\%) and running (13\%). The main barriers to doing sport in $2012 / 2014$ were: poor health (35\%), a lack of time (32\%), and lack of interest (17\%). Men and women tended to mention the same kinds of barriers - while a lack of time to do sport decreased with age, health concerns increased.

In the run up to the 2014 Referendum, the McLeish Report (2014) attempted to assess the case for Scotland as an independent Olympic participant. Published in May 2014 the report was not independent from the guidance set out in Scotland's Future (2014) in the sense that the latter paved the way for the former. It pointed out that around $11 \%$ of the athletes on UK

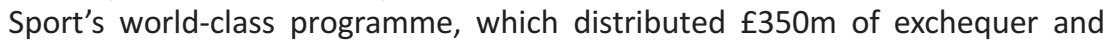




\section{Diplomacy and Influence through Sport}

Lottery funding every four years, were Scottish and that Scottish athletes made a contribution to one in five of the 65 medals won in London by Team GB (McLeish Report (2014: 18). Supporters of Scottish nationalism argued that Scotland's share of National Lottery investment in sport - estimated at around $\mathrm{f} 37 \mathrm{~m}$ - should be transferred to sportscotland. The UK government's position was that the entire basis of the National Lottery funding settlement would have to be revisited.

The question of Scotland's independent involvement in the 2016 Olympics and Paralympics was seen as a given on the basis that Montenegro and the Balkan States had received recognition within one year of independence and that Croatia and Serbia had been accredited in Olympic terms ahead of any United Nations membership. Yet such an assumption was challenged by one of the few Scots that have a place on the International Olympic Committee, Sir Craig Reedie. As a Vice-President of the International Olympic Committee, he warned that athletes would 'follow funding' and refuse to represent a newly independent nation' (Reedie, The Guardian 2014).

The McLeish Report placed an emphasis on physical activity as a catalyst to a healthier Scotland, but failed to address the role that sport has to play in international or cultural relations, and assumed, rather than critically assessed, the proposition that the solution was the transfer of further UK resources to Scotland despite sport having been devolved since 1999.

If the McLeish Report was confused about Scotland being a successful Olympic and Paralympic nation in its own right then it was less confused on a number of issues facing Scottish sport at the time. A number of actions were called for (i) a narrowing of the gap in sports participation between the least and most deprived groups (a 16\% difference amongst adults and a 19\% difference amongst children) McLeish, 2014: 5); (ii) a call for further opening up of the school estate supported by the fact that only $17 \%$ of indoor and $11 \%$ of outdoor space was utilized during school holidays (McLeish, 2014: 6); (iii) a review of the role of sport and leisure trusts given the divergent models across 32 local authorities, and a call for a more equitable model supporting disadvantaged communities and effective affordable pricing was called for (McLeish, 2014: 6); (iv) a recommendation that a continuing focus on high quality physical education needs to involve extended targets in both preschool and S5 and above, coupled with a focus upon improved teacher training ((McLeish, 2014: 39); and (v) that the state in the form of the Scottish Government should continue to have a role in the governance of sport and recognise the contribution sport makes to broader policy areas (health, education, justice, and tourism) and consider this investment as preventative spend. In other words, the Report concentrated on the domestic issues, 
aspects and values of sport; no mention of innovating the role of sport beyond its traditional character was made.

Similarly, the 2015 UK election manifestos from the Scottish political parties were very much 'business as usual' when it came to sport. They did little to provide confidence that the case for sport had climbed up the Scottish political agenda let alone acknowledge that was and is a valuable tool for international development, sub-state diplomacy and cultural relations. This was at a time when organisations such as the United Nations placed sport for development and peace on a statutory footing, illustrating the importance of sport in a globalized world (UN General Assembly: Session 7: Agenda 12-20 October 2015).

Scotland's claim to have a coherent, effective approach to government should recognise fully the benefits of a fresh attitude toward its formidable sporting traditions, history and impact. This would grasp sport's potential to promote Scotland, and better facilitate Scotland's external relations through UK offices.

It is our assertion that sport can play a major role in boosting Scottish influence abroad. For this to work in the best interests of Scotland and Scottish sport, however, it is essential that there is effective coordination between sport; culture; external relations; international development and Europe portfolios in the Scottish Government, and a similar restructuring of the Parliament's committee structure.

This can best be achieved through developing and implementing a coherent and dedicated strategy for the role of sport in Scotland's external relations. Only in this way, by coordinated effort, can we further Scottish influence both in sport and through sport. Unlike Australia, Scotland has no dedicated sports diplomacy strategy to guide how it should connect with people and institutions, enhance sport for development internationally, showcase Scotland and support innovation and integrity. As other countries dedicate more to their own levers of influence and resources (Australia suggests that about 3\% of GDP should be spent on sport) it is timely to consider what is the current state of play and what lessons Scotland might learn and adapt. Before this can occur, however, it is important to figure out who represents what in terms of Scotland?

\section{The State of the Debate}

International relations are reserved to Westminster under Schedule 5 of the Scotland Act 1998, and responsibility for the conduct of the UK's foreign policy and public diplomacy rests with the Foreign and Commonwealth Office (FCO) 


\section{Diplomacy and Influence through Sport}

in London with its 270 posts abroad (Murray, 2008). Scottish culture, values and interests are certainly presented through established UK channels such as the British Council and through UK initiatives such as the GREAT campaign, though these are very UK focused. Whether or not this means that Scotland's interests are adequately reflected in British diplomacy is contested, but Scotland does have access to a number of tried and tested diplomatic channels.

Nevertheless, Scotland can and does act internationally, in collaboration with the UK Government and its agencies, where required. The Scottish Government's international activities and priorities are set out in its International Framework, which was most recently updated in March 2015. The Framework sets out four strategic objectives:

- Enhance our global outlook to set the domestic conditions for success;

- Strengthen our external relationships, roles and networks;

- Build our reputation and international attractiveness, boosting our trade and investment; and

- Encourage engagement with the European Union.

To realize these objectives Scotland does engage in international contexts, mostly in relation to matters devolved under the Scotland Act, but also where Scotland has a direct interest in matters reserved to the UK.

A sizeable amount of literature (Creikemans, 2010; Huigh, 2012; Wyn Jones and Royles, 2012) already exists on sub-state diplomacy, as practiced by governments in Bavaria, Catalonia, Flanders, Quebec, Scotland, Wallonia and Wales, to name but a few. This type of diplomacy can be understood as

Subnational governmental involvement in international relations, through the establishment of formal and informal, permanent or ad hoc, contacts with foreign publics or private enterprises, with the aim to promote socioeconomic or political issues, as well as any other foreign dimension of their own constitutional competencies. (Cornago, 2000: 2)

In this definition of sub-state diplomacy, regardless of the avenues through which practice is pursued, the questions that may be asked about Scotland's activity in the pursuit of its interests are obvious:

- Which agency manages Scotland's external relations and what goals does it seek?

- What does, or should, Scotland represent to the global public? 


\section{Grant Jarvie, Stuart Murray and Stuart Macdonald}

- How are Scottish interests, values and culture projected and communicated abroad?

- How does Scotland create and sustain influence and reputation in a crowded marketplace where many countries are seeking attention and investment?

In terms of its current external relations the Scottish Government does have an External Affairs Directorate, whose purpose is 'to define and pursue our national interests beyond Scotland, and to enhance Scotland's reputation in Europe and internationally' (Scottish Government, 2015). The Directorate manages important relationships with North America, Europe, Africa and Asia, as well as the international development portfolio. Doctrinally, all of these relationships are informed via the International Framework described above which sets out Scotland's 'internationalisation agenda and objects' and the various 'contexts for delivery' (Scottish Government, 2015).

The bulk of Scotland's international (devolved) activities are carried out by Scottish Development International (SDI) and VisitScotland - the activities of business should be reflected including the Global Scot network and the efforts of bodies such as EDAS to start a debate about internationalisation. The key argument must be that a higher international profile through sport will address overall priorities for prosperity and for Scotland's initiatives in international development to support the common good.

Established in 2011, the Parliament also has a European and External Relations Committee, chaired by Christina McKelvie that meets on a weekly basis to consider the Scottish Government's international activities with Europe and further afield.

In August 2014, the Committee agreed to conduct an inquiry into Connecting Scotland, reviewing how the Parliament, its agencies and organisations engaged internationally. It missed, however, an opportunity to make specific recommendations around sport.

Despite all its good work, the Directorate has still to consciously consider embedding sport as a permanent means of creating Scottish influence, conducive to the four objectives of the International Framework. There are many reasons why sport is a beneficial for external relations through so-called 'sports diplomacy', which are explained below.

\section{Sports-Diplomacy, the Theory so far}

'Politics and sport don't mix' is a common adage to encounter when any mention is made of expanding the role of sport beyond the proverbial pitch. 


\section{Diplomacy and Influence through Sport}

Engaging with this opinion is, however, rather pointless. As the first section of this paper illustrated, politics and sport do mix, all the time.

The twentieth century provided many examples of sport and politics mixing: the Fascist Games (the 1934 and 1938 World Cups and the Berlin Olympics in 1936), the role Ping-Pong played in the thawing of Sino-U.S. relations in 1971, and the 1980 boycott of the Moscow Olympic Games by the United States (a gesture reciprocated by Moscow and thirteen satellite states four years later at the 1984 L.A. Games). ${ }^{4}$ Sport remains a potent vehicle for propaganda but it can also strengthen diplomatic relationships, facilitate connectivity and help societies recover from conflict.

Sport is often co-opted by governments to augment national and foreign policy goals. As Allison (1993: 17) notes, many types of governments,

Have endorsed international sporting competition as a testing ground for the nation or for a political 'system.' German Nazis, Italian Fascists, Soviet and Cuban Communists, Chinese Maoists, western capitalist democrats, Latin American juntas - all have played the game and believed in it.

Sport, in other words, has been employed by some nations as part of their foreign policy and diplomacy, a processes for how a state represents, communicates and realises its culture, values or interests abroad. At its most basic it is an administrative device, what Nicolson (1952: 15) refers to as the management of international relations by negotiation; the method by which these relations are adjusted by ambassadors and envoys; the business or art of the diplomatist.' In essence, diplomacy is a peaceful activity, 'the best means devised by civilisation for preventing international relations from being governed by force alone' (Satow, 1957: 1).

Diplomacy and soft power - the ability to 'attract' rather than 'coerce' (Nye, 1990) - are now thriving areas of theory and practice in contemporary international relations. Governments the world over are increasingly recognizing the value of culture, art, music, and sport as 'new' diplomatic tools. Of these, sport is prominent given its widespread appeal, media profile, and the fact that many international sporting structures, networks and partners are already in place. The importance of sport is twofold: first as a tool for promotion i.e to raise the profile of Scotland, and secondly - and more importantly - as a way of engaging Scotland at all levels from grass roots to elites in international activities which make connections, create networks and build relationships. IR research says that small nations need all the friends they can get, sport is a good way to do this for Scotland but of course also for other nations. 


\section{Grant Jarvie, Stuart Murray and Stuart Macdonald}

In a government context 'sports diplomacy' can be defined as the conscious use of sport by governments, politicians and diplomats; the employment of 'sportspeople and sporting events to engage, inform and create a favourable image among foreign publics and organisations, to shape their perceptions in a way that is (more) conducive to the sending government's foreign policy goals' (Murray and Pigman, 2013: 4). Sports diplomacy is an extremely useful and versatile tool in international relations. It can, for instance, transcend acrimony in diplomatic relationships, bring 'estranged' leaders together and generate informal pathways and dialogue beyond staid, formal venues and Westphalian playbooks. Since the early 1980s, for example, the leaders of bitter rivals India and Pakistan have met on the side-lines of cricket matches between their national teams. Cricket diplomacy has been employed as a way of decreasing tension over Kashmir, terrorism, trade, border and nuclear disputes.

Sport can also be used as a vehicle to test if the public of two countries are ready to move on; to presage tectonic shifts in embedded foreign policy positions. Such was the nature of the famous visit of the US Table Tennis team to China in April, 1971. Both the Mao and Nixon governments used this heavily covered event to gauge if the American and Chinese people were ready to accept the normalisation of diplomatic relations between the alienated Cold War adversaries. While Ping-Pong may sound trivial it did pave the way for U.S. National Security Adviser Henry Kissinger's secret visit to China in July, 1971, and Nixon's very public trip in February 1972, which he described as 'the week that changed the world' (cited in MacMillan, 2008: 3).

The use of sports 'ambassadors' - renowned athletes or basketball players, for example - is also common practice for governments. In the lead up to the 2008 Beijing Olympics, the Chinese government could not have asked for a more genial representative than the basketball player Yao Ming. During his time with the Houston Rockets (2002-2011), Yao attracted millions of Chinese fans to the National Basketball Association (NBA) and, vice-versa, exposed millions of Americans to the 'new' China. As James Sasser, the former U.S. Ambassador to China, notes, 'Yao Ming gave the Chinese people and China a human face in the United States' (in Zhang 2013: 229). Also, during the opening and closing ceremonies of the 2014 Sochi Winter Olympics two openly gay athletes figured prominently in the U.S. delegation. Billie Jean King and Caitlin Cahow (ice hockey) personified American disdain for Russia's draconian anti-Lesbian Gay Bisexual and Transgender (LGBT) policies. Clearly, ambassadors for, and of, sport can play a vital role in amplifying a government's intended diplomatic message. Although not an athlete, the John Barrowman kiss presented during the opening ceremony of the Glasgow 


\section{Diplomacy and Influence through Sport}

2014 Commonwealth Games in Glasgow carried a message to the 71 Commonwealth countries and territories that the Commonwealth Games Federation would challenge homophobic behaviour through the Games.

In addition, mega events such as the Olympic or Commonwealth Games generate massive public diplomacy opportunities for host nations. 1 billion people, or about $15 \%$ of the world's population, tuned in for the spectacular 2008 Beijing Olympics opening ceremony (Jackson and Haigh, 2008). If the strategic narrative, image and message are carefully crafted, foreign publics can be influenced, not to mention the boost to trade the host nation enjoys before, during and after the mega event. As Grix and Lee (2013: 1) note, South Africa (2010 World Cup) and Brazil (2014 World Cup and 2016 Olympics) coveted the tournaments as 'relatively cheap means of improving their image, credibility, stature, economic competitiveness' as well as their 'ability to exercise agency on the international stage.'

It is important to note that the benefits of using sport to promote Scotland and create influence are not without risks that need to be effectively managed and turned into opportunities to lead - and be seen to be leading - any drive for integrity in and through international sport. Disdain for a host nation can be expressed via mega-events. The decades-long boycotts imposed on apartheid South Africa are a well-known case, as were the Soviet and American boycotts of the 1980 and 1984 Games mentioned earlier. More recently, and during the Euro 2012 football tournament, the European Union (EU) boycotted football matches played in Ukraine because of the host nation's selective justice in the case of the jailed Ukrainian opposition leader Yulia Tymoshenko. Viviane Reding, the EU Justice Commissioner, pointed out that 'you cannot close your eyes on human rights, even during a great sporting celebration' (BBC News, 2012).

Such instances allude to a dark side to sports diplomacy. Something that the authors of this paper have commented upon extensively over the last decade or more (Jarvie, 2006; Jarvie, Thornton and Mackie, 2017). Furthermore, the authors are well aware that sport can be employed for anti-diplomatic purposes - however this article is not the appropriate place for either of these discussions, but it is acknowledged (Murray, 2012; Murray and Pigman 2013). For doubters and cynics, international sport can be hijacked and abused for national or personal gain. Sport also attracts rogues, cheaters, dopers, and corrupt administrators. The scandals that have befallen FIFA, Cycling and the IAAF have made headlines the world over, and reveal a perilous state of affairs in the global governance of sport. Moreover, international sport can at times parody international relations. For example, during the 2004 Asian Football Cup (hosted by China), Chinese spectators heckled the Japanese team, sang 
anti-Japanese songs from the war of liberation and 'displayed banners reading "Look into history and apologize to the Asian People", or "Return the Diaoyu (Senkaku) Islands!"' (Manzenreiter, 2008: 423). And, worryingly, terrorists are also attracted to sport, mainly for the dissemination of anti-diplomatic behaviours and messages. Between the 1972 Munich Games tragedy, when eleven Israeli athletes were kidnapped and murdered by Black September, a radical Palestinian organisations, and 2005 ' 171 sport-related terrorist attacks have been logged' (Jackson and Haigh, 2008: 351). For those interested in employing sport as a diplomatic tool an awareness of its dark side is important. However, when the amount of positive sporting exchange is considered, such bleak instances can be confirmed as the exception rather than the norm. Furthermore, in the context of this article it might also be argued that the expertise both within Scottish Universities and Scots working abroad is such that Scotland could capitalise more on knowledge exchange through sport in terms of addressing international sporting problems and issues.

\section{The State of International Practice}

Considering its versatility, appeal and global scope, more and more governments are beginning to develop permanent sports diplomacy strategies and policies. Part of the attraction is that sports diplomacy is relatively 'low-risk, low-cost and high profile' (Keech and Houlihan 1999: 112). Moreover, by engaging with new methods, the culture of a government's diplomacy can change from aloof, hermetic and 'dead,' to one that is innovative, effective, public and even fun (Ramsay 2006: 273). Scotland could learn from the efforts described below, leveraging its unique culture, ancient and modern sporting imprint for gain, at home and abroad. Working with the Tartan Army to promote goodwill towards Scotland is one often-cited example but many other forms of good practice exist.

The Americans were the first nation to introduce a specific sports diplomacy operation. The U.S. Department of State's vanguard initiative is the Sports United programme, which was born after 9/11 as a way of engaging young, disenfranchised people across Africa, the Middle East and South Asia. Sports United focuses on three main activities: Sports Visitors, where American Ambassadors nominate sports people from their host countries to travel to the U.S. for training and clinics; Sports Envoys, where U.S. athletes and coaches are selected to become global ambassadors of sport; and Sports Grants, which facilitate sport and education and training for 'non-elite kids 


\section{Diplomacy and Influence through Sport}

under seventeen years old' (Sports Diplomacy, 2014). The British Foreign and Commonwealth Office (FCO) has also engaged in sports diplomacy. Seeking to capitalise on the London 2012 Olympic Games, the FCO coordinated a network - the British Council, UNICEF, UK Sport, Comic Relief, Laureus Sport for Good Foundation, the Youth Sport Trust, and individual donors - which built and implemented a sports legacy programme called International Inspiration. Over the past three decades Japan has invested a small fortune in the J-league and the national football team, in order to 'to overcome imperial stereotypes,' and better reflect 'a level worthy of its economic power and overall achievements after 40 years of post-war peace and prosperity' (Manzenreiter, 2008: 417).

It is the Australians and their Department of Foreign Affairs and Trade (DFAT), however that have been the first to launch a dedicated Sports Diplomacy Strategy. Launched in June 2015 by Julie Bishop and Susan Hayne, the Foreign and Sports Ministers, respectively, the Strategy provides a 'dedicated point of contact, a portal' for absolutely anyone - players, coaches, sponsors, administrator and politicians at home or abroad - with an interest in Australian sport (Tranter, 2014). Built around four broad goals - connecting people and institutions, enhancing sport for development, showcasing Australia, and supporting innovation and integrity - the Strategy aims to grow the 'value and influence of Australia's sport credentials and assets in the Indo-Pacific region and beyond' (Australian Government, 2015: 2). As Bishop (2015) noted at the launch, the Strategy

Signals a new era of partnership between the Australian Government and sporting organisations. Together, we will leverage our outstanding sports skills, facilities and knowledge to promote Australia and strengthen our links with countries and communities in the region.

These are very similar goals to the Scottish Government's International Framework.

Where the Americans, British and Australian nations lead, others with a rich sporting pedigree will surely follow. Zhang (2013) reminds us that China has a long history of sports diplomacy, both old and new. With current President Xi Jinping keen to enhance China's use of soft power, expect to see a sports diplomacy strategy with Chinese characteristics emerging soon. Besides finishing second on the medal table at the 2012 London Olympics, and winning the rights to host the 2022 Winter Olympics, China intends to bolster its image abroad via football. The sport is now part of the national curriculum, 20,000 football-themed schools are due to open by 2017 (with the goal of producing more than 100,000 players), and Xi himself recently announced 


\section{Grant Jarvie, Stuart Murray and Stuart Macdonald}

three, personal ambitions for China: to qualify for the world cup, to host the event, and finally, one day to win it (Wan, 2015: 11).

Similarly, and as a result of the Joint Plan between Iran and the P5+1 powers (the five permanent members of the United Nations Security Council, plus Germany), Iran is beginning the long road of re-engaging the world via soft as well as ongoing, hard power initiatives. After decades of isolation, Tehran is already contemplating how to build public, cultural and sports diplomacy strategies that reflect and represent a deep love and history of pursuits based on the finer aspects of humanity. Other nations that see sport as part of their international identity, such as Brazil, Canada, Cuba, India, Kenya, South Africa, New Zealand, and so on, are likely to follow suit. Scotland, blessed with world class sporting facilities, sportspeople and fans, and an envious range of unique, indigenous and cultural sports, could benefit from coordinating, synergizing and codifying its domestic and international sporting presence in a similar fashion. To facilitate, a number of recommendations for those interested in developing a Scottish sports diplomacy strategy are outlined in the following section.

\section{Scotland, Sports Diplomacy and Influence: Recommendations}

As the above discussion illustrates, sports diplomacy and influence is an increasing area of theory and practice of international relations and diplomacy. Building on the historical precedent of using sport and sporting events to mediate estrangement between disparate nations, sports diplomacy is simply the reification, coordination and specialisation of a familiar aspect of inter-national affairs, on a permanent as opposed to sporadic basis. Should the Scottish Government wish to proceed down the sports diplomacy path, an awareness of the following issues could pay dividends.

First, it is important to confirm that Scotland is a sub-state actor with a unique history, values, interests and culture which it represents and communicates abroad. Over the past few years Holyrood has developed a sub-national approach to external relations with specific policy objectives it wishes to achieve. In this context, it becomes entirely reasonable to think about how to enhance the Scottish government's use of soft power tools such as music, culture and sport, conducive to strengthening relationships, and increasing Scotland's attraction and reputation as a place to visit or invest in. Scottish sports diplomacy needn't clash with or duplicate the UK Government's work in this area. Indeed, it should aim to complement it, working within the existing framework while recognising that 


\section{Diplomacy and Influence through Sport}

Scotland has its own interests which may require a specifically Scottish approach.

Second, to build an effective strategy it is important to engage in a bit of network topography. In the first section of this paper we described the complex landscape of sporting governance in Scotland but stopped short of describing the various domestic clubs, national sports associations, media outlets, businesses and the many non-state or civil society organisations that consider sport as their major currency. It is vital that any strategy recognises the 'multistakeholder' nature of sports diplomacy, and that those responsible for implementation should have an awareness of their role as the centre of a plural network, composed of horizontal and vertical channels, populated by a myriad range of actors, both state and non-state.

To validate the importance of thinking in networked terms, Australia's DFAT once more provides a case in point. Part of the success behind their Strategy lay in envisaging their role as a 'hub' at the centre of a network. In the words of the main architect of that Strategy, Rob Tranter (2014), their first job was to map the network, to 'join the dots'. Early on DFAT advertised that it was not out to impinge on others' territory but to develop mutual areas of interest, coordinate with other agencies, and to leverage sport 'for mutual and strategic advantage' (Roberts, 2014).

Third, in order to avoid turf wars, or internecine power struggles over who owns what in Scottish sport, it would be important to establish a working group, open to all parties interested in having a conversation in how to better leverage Scottish sport for the benefit of all. Its purpose could be to seek input, explain the Government's new attitude toward using sport as a 'diplomatic' tool, delineate territories, assign roles, share resources, coordinate activities and, where possible, avoid duplication.

Fourth, as part of these discussions it is important to figure out how Scottish sports diplomacy could boost current international activities. How, for example, might Scottish sport help realise the four international objectives of the Scottish Government's International Framework? How might sport dovetail with extant forms of public and cultural diplomacy, such as Scotland Week, Tartan Day, diaspora engagement and the celebration of St. Andrew's Day and Burns Night? And, what role could Scottish sport play in boosting the Government's international development goals? Sport for Development (SFD) is a well-established area of theory and practice, has a track record of success in helping stricken, war-torn or developing nations heal and move on, and often secures generous support from powerful international sports federations, non-governmental organisations 


\section{Grant Jarvie, Stuart Murray and Stuart Macdonald}

and prominent sports stars, occasionally working 'in partnership with government departments of education and health' (Kidd, 2008: 373). As has been the case with American, Japanese or Australian sports diplomacy, SFD initiatives are often bolstered by being subsumed under a Whole of Government approach.

Fifth, in writing an actual Scottish strategy, there is no need to reinvent the wheel, so to speak. The Australians borrowed much of their model from the Americans, and it is likely China and Iran's future strategies will revolve around the key elements of sports envoys, exploiting mega events for public diplomacy purposes, sport for development, and exchanges with young people, athletes and coaches from overseas. In people like Katherine Grainger, Ian McGeechan, Michael Jamieson, Andrew Murray and Eve Muirhead Scotland has a wealth of ready-made ambassadors for Scottish sport. It also has a wealth of excellent facilities, as well as a capacity for successfully hosting mega events. A global television audience of 620 million watched the 2015 British Open at St. Andrews, and - according to the Organising Committee of the Glasgow Commonwealth Games - one billion tuned into to witness the opening ceremony of the 'best ever' Games (BBC news 2014). As noted earlier in the paper, such events can generate massive public, cultural and sports diplomacy opportunities.

Sixth is the question of British Council sponsorship of Scottish sports projects along the same lines as sponsoring of Premier Skills football in China or the recent award winning, 2015 Peace and Sport award, DOSTI initiative in Pakistan. This uses sport as a medium to cut across socio/ cultural barriers and help both young people and communities in Karachi find common ground to foster intergroup understanding, tolerance and an appreciation for diversity by addressing conflict. The essence of these and other initiatives is to foster international development and cultural relations through the British Council but few Scottish sports initiatives are supported or are forthcoming. In short Scottish sport should maximise idiomatic opportunities as well as those generated by existing British cultural relations avenues.

Finally, it is also worth noting that if Scotland wishes to formulate a sports diplomacy strategy, it needn't break the bank. In the Australian case, much of the groundwork, design, coordination and implementation of the Strategy were carried out by five diplomatic staff, working in a Department that remains under intense budgetary pressure. Their proactive attitude demonstrates that much can be achieved with little. Scotland might like to think about public/private partnerships and sponsorship through broadcasting, for example, as but one way forward. 


\section{Diplomacy and Influence through Sport}

\section{Concluding Remarks}

The world today is in many ways an uncertain place and Scotland, like others, faces complex strategic issues. The question posed is whether or not Scotland can afford to ignore any avenue that potentially can mitigate risk and influence mutual understanding? Sport matters in the global, plural twenty-first century not simply because nations can create influence and status within sport but more importantly nations can create influence through sport. Given the nature of current challenges, soft power, a revised understanding of the nature and role of Scottish diplomacy, and effective, concomitant cultural relations are critical to securing influence, trust, mutual understanding and connectivity.

Sport is a powerful and universal language that, if harnessed, can build comity in the place of estrangement, and unite disparate nations and publics through mutual affinities. Sports diplomacy can also strengthen old and new relationships, and increase the brand of a nation as a modern, innovative and friendly place for investment, or simply a place to visit. Sports diplomacy is not necessarily axiomatic with the state, and smaller nations and sub-states need to be bold and innovative in how they attract trade, tourists and publics. Marrying tried and tested soft power means such as sports diplomacy to Scotland's powerful brand, culture and values, is one dynamic way to do so.

\section{Notes}

1. The authors are grateful for the feedback provided by the anonymous reviewers and acknowledge that the article is stronger as a result of this input.

2. The University of Edinburgh Centre for Cultural Relations is trying to stabilise the definitions https://en.wikipedia.org/wiki/Cultural_relations.

3. The Scottish Sports Association and the Common Weal think tank both produced position papers designed to influence the 2016 Scottish Parliamentary Election while the national sports agency has produced a new corporate plan to cover the period 2015-2019.

4. Mussolini sought to use football to mobilise support for fascism. Italy won both world cups in 1934 and 1938 (as well as the gold medal at the 1936 Olympics). The team wore black shirts in France, 1938 and, to boos and whistles, performed the fascist salute before each game.

\section{References}

Allison, L. (1993). The Changing Politics of Sport. Manchester: Manchester University Press.

Australian Government (2015). Australian Sports Diplomacy Strategy, 2015-18. Canberra: Parliament of the Commonwealth of Australia. 


\section{Grant Jarvie, Stuart Murray and Stuart Macdonald}

BBC news (2012). Tymoshenko case: Europe pressure on Ukraine intensifies. Viewed 13 November 2015, http://www.bbc.co.uk/news/world-europe-17892514.

BBC news (2014). Glasgow 2014: Organisers reveal ticket sales and other Games facts and figures. Viewed 13 November 2015, http://www.bbc.com/news/uk-scotlandglasgow-west-28722157.

Bishop, J. (2015). New era in sports diplomacy. Media Release, Minister for Foreign Affairs, June 25. http://foreignminister.gov.au/releases/Pages/2015/jb_mr_ 150625a.aspx.

Cornago, N. (2000). Exploring the global dimensions of para-diplomacy: Functional and normative dynamics in the global spreading of subnational involvement in international affairs. In: Workshop on Constituent Units in International Affairs. Hanover, Germany.

Criekemans, D. (2010). Regional sub-state diplomacy from a comparative perspective: Quebec, Scotland, Bavaria, Catalonia, Wallonia and Flanders. The Hague Journal of Diplomacy 5(1): 37-64.

Der Derian, J. (1987). Meditating Estrangement: A Theory for Diplomacy. Review of International Studies, 13: 91-110.

Fisher, A. (2013). Collaborative Public Diplomacy. London: Palgrave.

Grix, J and Lee, D. (2013). Soft Power, Sports Mega-events and Emerging States: The Lure of the Politics of Attraction. UK [online]. Centre for Rising Powers working paper no. 12., Cambridge: CRP, viewed 21 February, 2015, http:// www.crp.polis.cam.ac.uk/documents/working-papers/crp-working-paper-12-grixand-lee-mega-sports.pdf.

Haynes, N. (2014). Scotland's Sporting Buildings. Edinburgh: Historic Scotland.

Hocking, B. (2006). 'Multistakeholder Diplomacy: forms, functions and frustrations'. In Multistakeholder Diplomacy: Challenges and Opportunities, edited by Jovan Kurbaliga and Valentin Katrandjiev, 13-33. Malta: DiploFoundation.

Huigh, E. (2012). The future of sub-state diplomacy. Public Diplomacy Magazine 8: $22-30$.

Jackson, S. J. and Haigh, S. (2008). Between and Beyond Politics: Sport and foreign policy in a globalizing world. Sport in Society, 11(4): 349-358.

Jarvie, G. (2006). Sport, Culture and Society. London: Routledge.

Jarvie, G and Burnett, J. (2000). Sport, Scotland and the Scots. East Linton: Tuckwell Press.

Jarvie, G, Thornton, J and Mackie, H (2017). Sport, Culture and Society, $3^{\text {rd }}$ edition. London: Routledge.

London School of Economics (2015). Moving the Goalposts: Poverty and Access to Sport for Young People. London: LSE Report.

Keech, M. and Houlihan, B. (1999). Sport and the end of apartheid. The Round Table: The Commonwealth Journal of International Affairs, 8(349): 109-121.

Kelly, P. (2015). 'Health benefits of different sports disciplines for adults: systematic review of observational and intervention studies with meta-analysis'. British Journal of Sports Medicine. Published online 1 July 2015. 


\section{Diplomacy and Influence through Sport}

Kerr, P. and Wiseman, G. (2013). Diplomacy in a Globalizing World: Theories and Practices. Oxford: Oxford University Press.

Kidd, B. (2008). A new social movement: Sport for development and Peace. Sport in Society 11(4): 370-380.

Mattingly, G. (1938). An Early Nonaggression Pact. Journal of Modern History 10(1): $1-30$.

MacMillan, M. (2008). Nixon and Mao: The Week That Changed the World. London: Random House.

Manzenreiter, W. (2008). Football Diplomacy, Post-Colonialism and Japan's Quest for Normal State Status. Sport in Society 11(4): 414-428.

McLeish Report. (2014). Scotland's Sporting Future. Edinburgh: Scottish Government.

Murray, S. (2008). Consolidating the gains made in diplomacy studies: a taxonomy. International Studies Perspectives 9(1): 22-39.

Murray, S. (2012). The two halves of sports-diplomacy. Diplomacy and Statecraft 23(3): 576-592.

Murray, S. \& Pigman, G. A. (2013). Mapping the relationship between international sport and diplomacy. Sport in Society 17(9): 1098-1118.

Nicolson, H. (1952). Diplomacy. Oxford: Oxford University Press.

Nye, J. (1990). Bound to Lead: The Changing Nature of American Power. New York, NY: Basic Books.

Ramsay, A. (2006). Is Diplomacy Dead?? Contemporary Review, autumn (288): 268-275.

Reedie, C. (2014). Scotland team may miss Rio Olympics in event of vote for independence'. The Guardian. 6 September, 11.

Roberts, Martin (Adviser, Sports Diplomacy), interview by Stuart Murray, Department of Foreign Affairs and Trade, Canberra, October 30, 2014.

Satow, E. (1957). A Guide to Diplomatic Practice, 4th edition. London: Longmans, Green \& Co.

Scottish Government, the (2015). External Affairs Directorate. Viewed November 13, 2015, http://www.gov.scot/About/People/Directorates/ex-affairs.

Scottish Health Survey (2014). Viewed 5 November 2015 at http://www.gov.scot/ Topics/Statistics/Browse/Health/scottish-health-survey.

Scottish Parliamentary Briefing Paper (SPICE, 2015). SP 15-87 draft budget for health and sport 2016-17. Edinburgh: SPICE. http://www.parliament.scot/ ResearchBriefingsAndFactsheets/S4/SB_15-87_Draft_Budget_2016-17-_Health_ and_Sport.pdf.

Scottish Sports Hall of Fame (2015). Viewed 3 December 2015, http://www.sshf.co.uk. Sharp, P. (2009). Diplomatic Theory of International Relations. Cambridge: Cambridge University Press.

Skillen, F. (2013). Women and Sport in Inter-War Britain. Oxford: Peter Laing. Sportscotland Corporate Plan (2015). Raising the Bar. Edinburgh: Sportscotland.

Sports Diplomacy n.d., Bureau of Educational and Cultural Affairs, Washington, viewed 15 August 2014, http://eca.state.gov/programs-initiatives/sports-diplomacy. 
Tranter, N. (1998). Sport, Economy and Society 1750-1914. Cambridge: Cambridge University Press.

Tranter, R. (First Assistant Secretary, Public Diplomacy and Communications Division), interview by Stuart Murray, Department of Foreign Affairs and Trade, Canberra, October 30, 2014.

United Nations (2015). United Nations General Assembly resolution 20 on Sport, Peace and Development. 20 October 2015. Viewed 6 November at http://www.un.org/ wcm/content/site/sport/home/template/news_item.jsp?cid $=42879$.

Wan, W. (2015). China's Xi Jinping loves football so much he's put it on the national curriculum - but can he secure the World Cup? The Independent Newspaper, p. 11.

Wyn Jones, R. and Royles, E. (2012). Wales in the world: Inter-governmental relations and sub-state diplomacy. The British Journal of Politics and International Relations 14(2): 250-269.

Zhang, Q. (2013). Sports Diplomacy: The Chinese Experience and Perspective. The Hague Journal of Diplomacy, 8(304): 211-233. 


\section{Your short guide to the EUP Journals Blog http://euppublishingblog.com/}

A forum for discussions relating to Edinburgh University Press Journals

\section{The primary goal of the EUP Journals Blog}

To aid discovery of authors, articles, research, multimedia and reviews published in Journals, and as a consequence contribute to increasing traffic, usage and citations of journal content.

\section{Audience}

Blog posts are written for an educated, popular and academic audience within EUP Journals' publishing fields.

\section{Content criteria - your ideas for posts}

We prioritize posts that will feature highly in search rankings, that are shareable and that will drive readers to your article on the EUP site.

\section{Word count, style, and formatting}

- Flexible length, however typical posts range 70-600 words.

- Related images and media files are encouraged.

- No heavy restrictions to the style or format of the post, but it should best reflect the content and topic discussed.

\section{Linking policy}

- $\quad$ Links to external blogs and websites that are related to the author, subject matter and to EUP publishing fields are encouraged, e.g.to related blog posts

\section{Submit your post}

Submit to ruth.allison@eup.ed.ac.uk

If you'd like to be a regular contributor, then we can set you up as an author so you can create, edit, publish, and delete your own posts, as well as upload files and images.

\section{Republishing/repurposing}

Posts may be re-used and re-purposed on other websites and blogs, but a minimum 2 week waiting period is suggested, and an acknowledgement and link to the original post on the EUP blog is requested.

\section{Items to accompany post}

- A short biography (ideally 25 words or less, but up to 40 words)

- A photo/headshot image of the author(s) if possible.

- Any relevant, thematic images or accompanying media (podcasts, video, graphics and photographs), provided copyright and permission to republish has been obtained.

- Files should be high resolution and a maximum of $1 \mathrm{~GB}$

- Permitted file types: jpg, jpeg, png, gif, pdf, doc, ppt, odt, pptx, docx, pps, ppsx, xls, xlsx, key, mp3, m4a, wav, ogg, zip, ogv, mp4, m4v, mov, wmv, avi, mpg, 3gp, $3 g 2$. 